\title{
ANALYZES OF AUTUMNAL, WINTER AND SPRING FROST DAMAGE AT THE WINE REGIONS OF HUNGARY
}

\author{
L. LAKATOS ${ }^{1}$, S. MOLJÁK. ${ }^{2}$, R. NAGY ${ }^{3}$
}

\begin{abstract}
While frost is a natural phenomenon in Hungary from autumn to spring, the frost damage, causing crop damage and yield reduction or even harvest shortfall, does not occur every year. The aim of the study was to estimate the occurrence and frequency of frost damage in autumnal, winter and spring frost damage from the CarpatClim data base, in the wine regions of Hungary. Determining the daily distribution of the $\mathrm{LT}_{50}$ function between September 7 and May 15, with the Cold Hardiness model which contains 23 grape varieties, the occurrence probability of autumnal, winter and spring frost damage can be accurately determined. The extent of frost damage, frost duration and strength of frost is significantly affected by tolerance of grape varieties. We analysed the extent of autumnal, winter and spring frost damage respectively at frost susceptible, moderately frost-tolerant and frost-tolerant grape varieties. We examined the stepovers of frost damage thresholds by using CARPATCLIM database during the period between 1961-2010. The results provide not only frost damage quantification, but they may also help to judge the complex value of cultivation areas more accurately and to parameterize the crop safety of wine regions.
\end{abstract}

Keywords: frost damage, LT50 function, wine regions, wine grapes, CarpatClim data

\section{INTRODUCTION}

Frost is one of the most extraordinary phenomena in nature. Although from a meteorological point of view the frost cannot be considered an extreme process in the environment, because it is just a narrow part of the temperature range in our Earth. Nevertheless, it can cause significant irreversible physiological changes in the living cells. By the results of frost occurrence as cell destruction and dehydration we can get serious frost damage at most plants species. For the national viticulture, it is very important to determine the temporal changes of frost occurrences in the major wine regions of Hungary. The occurrence of frost from autumn to spring is a natural climatic feature of our country. If the temperature is lower than the frost tolerance threshold value of a given variety, we can talk about

\footnotetext{
${ }^{1}$ Eszterhazy Karoly University, Dep. of Environmental Sciences and Ladscape Ecology, H-3300 Eger, 6-8 Leányka st., lakatos.laszlo@uni-eszterhazy-hu

${ }^{2}$ EKU-Innoregion Knowledge Centre, H-3300, Eger, 6-8 Leányka st., moljak.sandor@unieszterhazy.hu

${ }^{3}$ EKU-Innoregion Knowledge Centre, H-3300, Eger, 6-8 Leányka st., nagy.richard@unieszterhazy.hu
} 
frost damage. In previous frost studies (Oláh, 1979) the researchers determined probabilities and the frequency of different threshold temperature days' occurrences which are risky for grape (Dunkel, Kozma, 1981).

They studied the effects of climatic scenarios not only on the earlier used temperature threshold categories, but also introduced new minimum temperature index categories, such as $-15^{\circ} \mathrm{C}$ and $-18^{\circ} \mathrm{C}$ (Szenteleki et al., 2011), so they analysed the number of frosty days below these temperature thresholds as well. As our climate is warming fewer days occurs below $-21^{\circ} \mathrm{C}$. If we wish to introduce changes of these days' occurrences in decades, it can easily happen that there will not be data at all. So, we will not characterize the extent of the changes. The occurrence of frost damage at the main cultivation areas of apricot and peach orchards have been studied more (Szalay et al., 2000; Lakatos et al., 2005). Not only the frost, but the incidence of frost damage is being studied previously in our country. These studies were dealing with mainly frost damage occurring apricot and peach orchards (Szalay et al., 2000; Lakatos et al., 2005). Knowing the $\mathrm{LT}_{50}$ function values during the acclimation, maximum hardiness and the deacclimation periods of wine grapes, the probability of frost damage occurrence can be accurately determined. By using the varieties $\mathrm{LT}_{50}$ functions we can quantify the extent of frost damage in wine regions for the most common grape cultivars. The frost damage calculation help us to quantify the cultivation risk of wine grape production and we can develop a new land evaluation methods and we can improve the crop safety as well (Lakatos et al., 2006).

\section{MATERIAL AND METHODS}

We used CARPATCLIM database to examine frost damage in time and space. We analysed daily minimum temperatures in the period between 1961-2010. The available climate data does not extend to all of the country, from the 22 domestic wine regions; we only tested (Figure 1).

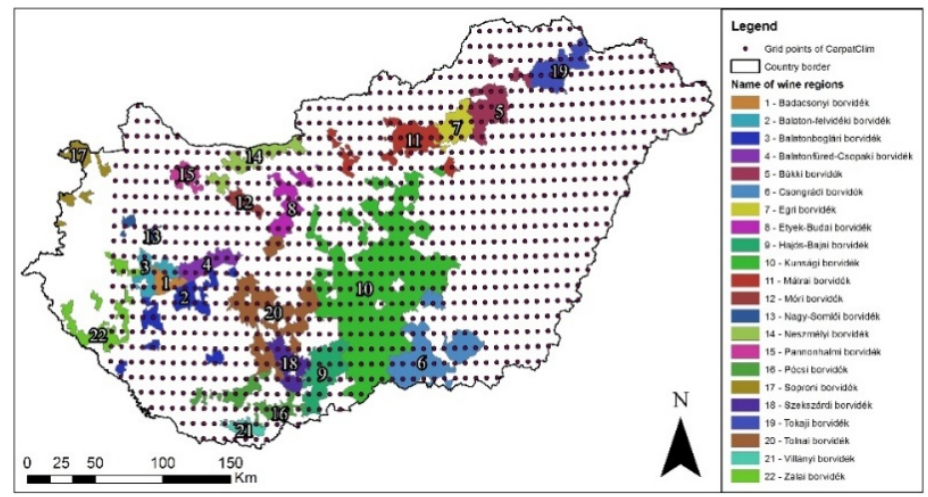

Fig.1. National grid points of CarpatClimdatabase and location of the domestic wine regions 
This however shows quite a variancy throughout the wine regions, as Kunsag wine region can be analysed based on 100 lattice points while NagySomlo, Badacsony, Villany, Mor can only be analysed based on 3 lattice points.Sopron wine region is not included in the study and it did not cover the whole of the Zala wine region, as the region continues beyond the available database. The 7 lattice point covers approximately two-thirds of the wine region's area, so we thought that we do not exclude this region from the study and to characterize the wine region with these data points. On average, 14-point grid data are available to characterize a wine.

To show the results in space ArcMap 10.4 GIS software was used. Based on the data we have created a network of points $\left(0.1^{\circ} \mathrm{x} 0.1^{\circ}\right)$ and paired the results to corresponding points. With the value of points using spline interpolation process raster maps were generated. The spline interpolation is a function that, following the shape of "flexible membrane“ estimates the value of the intermediate points, minimizing the total curvature of the surface based on a fixed value of input points. The result is a smooth surface that includes the value of each input point, but with minimum curvature of the surface.

\section{DERIVATION OF LT50 VALUES}

To define frost damage is a slightly more complicated task. We can determine the extent to which parts of plants, shoots or buds freeze-the amount of frost damage- by placing plant samples in frost chambers. If cooled to a certain temperature, the test plants, or parts, then some samples die completely, while others do not suffer any damage after warming. Knowing the minimum lethal temperatures (LT) we can determine how long the plant parts can be cooled without causing permanent damage. The LT value of plant species and breeds differ considerably. There are excellent, good, or less frost-resistant varieties. The frost susceptibility tests are intended to determine exactly the percentage of damaged plant samples at given temperatures below the freezing point (Millset al., 2006). In general, three lethal temperature categories, ie frost damage categories are examined, $\mathrm{LT}_{10}, \mathrm{LT}_{50}$, and $\mathrm{LT}_{90}$ values. The $\mathrm{LT}_{10}$ means that if the temperature is lower than the lethal temperature, $10 \%$ of the plant samples tested, for $\mathrm{LT}_{50} 50 \%$, whereas at $\mathrm{LT}_{90} 90 \%$ of the plant parts suffer frost damage. The present study determined the $\mathrm{LT}_{50}$ value using the model developed by Washington State University (Ferguson et al., 2011). Determination of the minimum lethal temperature causing at least a frost damage of $50 \%$ was made on the basis of the 50-year averages. $\mathrm{LT}_{50}$ function was determined to each wine region separately, determined by the average. The model's input parameters were the daily minimum, maximum and average temperatures. Instead of determining annually in this study we determined the minimum lethal function on the basis of daily average values of several years.

We did not consider the impact of the yearly different temperature conditions, as a comparison of the vintage was not the goal, but the determination of frost susceptibility and frost risk of wine, and the production of daily data from September 7 - to May 15 for each wine region proved to be perfectly suitable The model 
defines the course of lethal minimum function for 23 types of grapes, for total rest period (Ferguson J. C. et al., 2014).

We created the $\mathrm{LT}_{50}$ graph for 21 wine regions and 11 grape types based on the daily average temperature of several years and the minimum and maximum temperatures. Among the grape types there are some types that are particularly frostresistant, like Riesling and Chardonnay, some moderately sensitive types, like Cabernet Sauvignon and Merlot, and some frost-sensitive types, like Sémillon or Mourvèdre. However, there is a big difference among the types when we examine their tolerance to seasonal frost. A grape type that is frost-resistant in winter might be extremely sensitive to frost in spring. An example is Lemberger, which expresses very good frost tolerance capability in winter, while in spring it proved to be one of the most frost-sensitive types among the tested varieties. Looking at the $\mathrm{LT}_{50}$ graphs we can state that the probability of frost damage with which the domestic grape types (or the types that might be suitable for Hungarian cultivation in the future) could be adapted to the domestic climatic conditions. With the help of the available model we determined the $\mathrm{LT}_{50}$ values by grape types and places of cultivation between September 7 and May 15, based on the daily average temperature of several years and the minimum and maximum temperatures of the different places of cultivation. The so derived function only contains temperature parameters, and does not take into account the values of the moisture of the soil in autumn and its changes, nor the evolution of the moisture content of the canes at the end of the growing season.

There are significant differences in the course of the $\mathrm{LT}_{50}$ functions for the different wine regions and types during the time period under review. When we examine the wine region of Eger, it is clear that Lemberger is one of the most frostresistant types in autumn and winter, but in spring it is one of our most frostsensitive grape types (Figure 2).

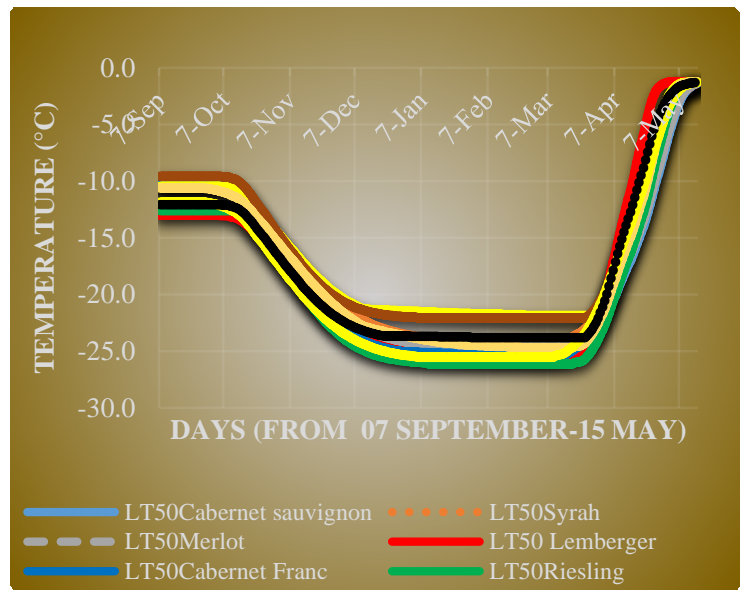

Fig. 2. Daily distribution of minimum lethal temperature functions $\left(\mathrm{LT}_{50}\right)$ of tested wine grape varieties between $7^{\text {th }}$ September and $15^{\text {th }}$ May at Eger wine region 
Riesling was proved to be one of the most frost-tolerant varieties among the examined ones, but in the autumn Kékfrankos surpasses its frost tolerance. Not surprisingly, between the Mediterranean and the domestic varieties the difference of maximum frost tolerance in winter can reach up to 5 degrees Celsius. The difference between the frost tolerances of grape types is the biggest in spring, at the end of April. The difference between the $\mathrm{LT}_{50}$ graph values calculated by the model can reach up to $8^{\circ} \mathrm{C}$ as well.

\section{RESULTS}

In forming the 11 grape types' lethal minimum functions based the wine regions, it becomes possible to determine the incidence of autumnal, winter and spring frost damage. In addition, we can calculate the probabilities of annual frost damage in the 21 wine regions. While the frost occurrence probability for the autumn and spring growing season is the same, the rate of frost damage is significantly higher in spring than in the autumn. Regarding all the wine regions, the springtime frost damage is far the highest. More than, two third $(68 \%)$ of the frost damages occur in that period. The winter frost damage is closely following this rate with its $29 \%$. Interestingly, only $3 \%$ of the frost damage occurs in the autumn period (Figure 3).

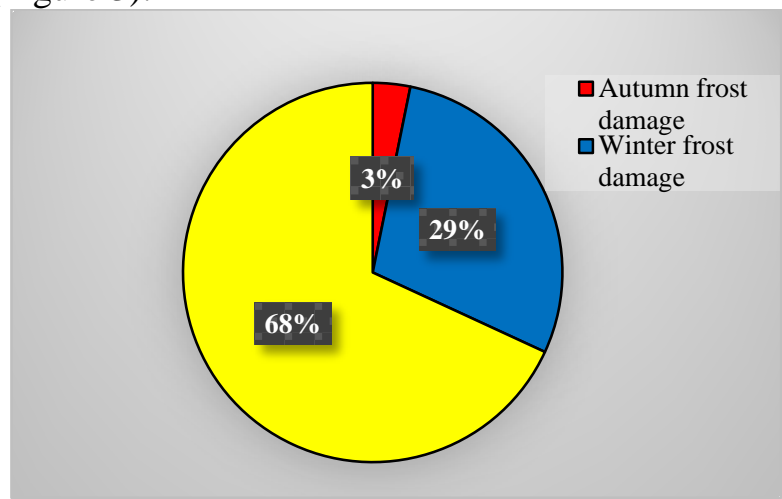

Fig. 3. Relative frequency distribution of autumn, winter and spring frost damage of domestic wine regions between 1961-2010

During the analysis of the varieties' frost damage probability, the data showed that the autumnal frost damage probability is low and there is no significant difference between the frost tolerances of the varieties. The Cabernet Sauvignon and Merlot species can be considered a bit more frost-sensitive than the other examined varieties (Figure 4). In the winter period, the Mediterranean varieties (Semillon, Mourvédre) have the largest probability for frost damage. In spring, the Lemberger variety have a significantly high risk for frost damage. The probability that the Lemberger cultivars suffer frost damage in the springtime in any wine regions of Hungary is more than $70 \%$. In comparison, the frost damage 
risk of Pinot Gris, which is the second most susceptible domestic cultivar in Hungary, is significantly lower, „only“ $50 \%$ in the spring period.

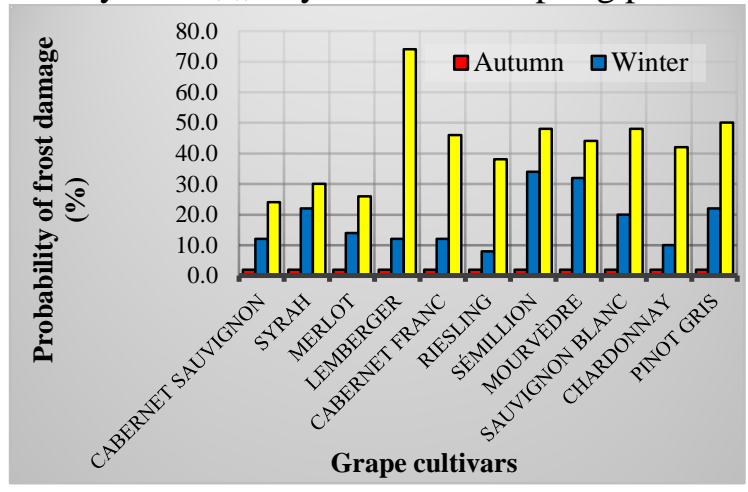

Fig. 4. Seasonal distribution of at least $50 \%$ probability frost damage on wine grape cultivars at domestic wine regions of Hungary between 1961-2010

The above mentioned results certainly do not apply to wine-growing regions as a whole. In the case when frost damage occurred in one data point of the region, we considered it frost damaged. In this case, the minimum temperature was lower than the pertaining $\mathrm{LT}_{50}$ function's value. If we analyze in details how the regional rate of frost damage in the wine regions was spread for examined breeds, we can make the following observations:

Despite the fact that the autumntime and springtime frost probability is the same, the occurrence of frost damage in spring is much higher than during the autumnal period. However, the autumnal spatial rate of frost damage is significantly higher than that of the springtime's.

Especially the Mediterranean varieties (Sémillion, Mourvédre) represented extensive frost damage, but the rate did not exceed $40 \%$ (Figure 5).

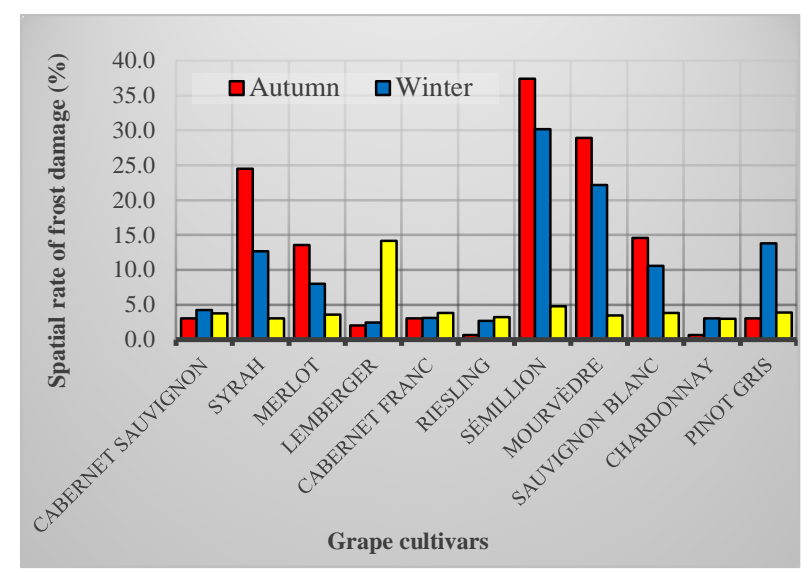

Fig. 5. The spatial distribution of frost damage on wine grape cultivars at domestic wine region of Hungary between 1961-2010 
These two cultivars show a 6-7\% lower value during the wintertime. The regional rate of spring frost damage usually remains below 5\%.The Lemberger's spatial frost damage rate, which is a very frost sensitive cultivar, does not exceed $15 \%$ (Figure 5). To sum it up, frosts appear in small-area ratios of the domestic wine regions and very rarely affect the whole of the region. Since we cannot be sure about where and when will the frost damage occur, it is worth preparing for long-term frost protection in every wine region.

In the spatial distribution of springtime frost damage, the cold advection also plays a significant role. The risk of frost occurrence is more significant in those years when the northern cold and dry air flows into the country. In other words, when the anticyclone is situated west of the country or when the Carpathian Basin is in the center of the anticyclone. While most of the wine grapes do not suffer much damage in late April or early May in case of a $-5 \ldots-6^{\circ} \mathrm{C}$ frost, the Lemberger can reach up to a $50 \%$ or greater frost damage rate in case of a $-1^{\circ} \mathrm{C}$ temperature. The most sensitive wine regions to frost damage during spring are Csongrad, Matra and Neszmélyi (Figure 6).

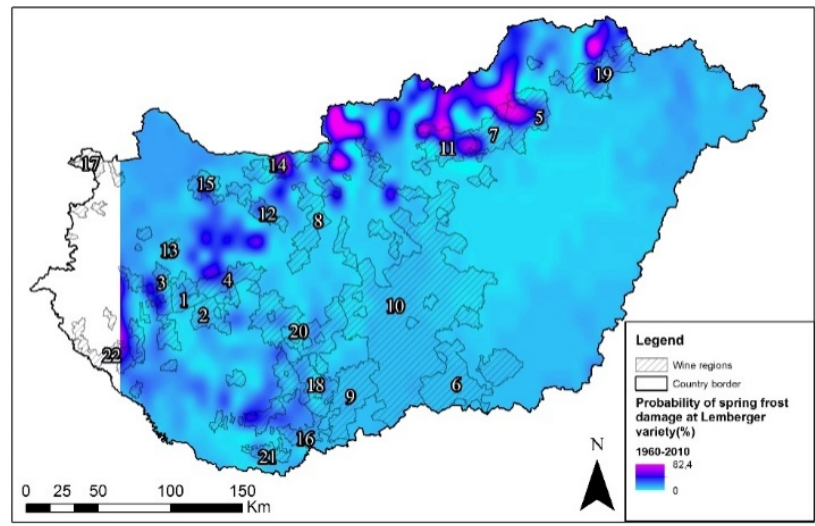

Fig. 6. The spatial distribution of spring frost damage of Lemberger wine grape variety at domestic wine regions of Hungary between 1961-2010

\section{CONCLUSION}

During the rest period, only the extremely low minimum temperatures could cause serious frost damages, while in the vegetation period, lower temperatures like $-1^{\circ} \mathrm{C}$ can result in severe frost damage.

Following up plants' responses to the weather elements, vineyards will have to take the necessary measures to ensure the smooth development of the stock and protect them against adverse effects.

If we know the statistics of frost occurrence and the probabilities of frost damage formations, we have the opportunity to recommend the optimal yields to the domestic wine regions. 


\section{Acknowledgements:}

Authors used data and maps from the following article: CARPATCLIM Database (C) European Commission - JRC, 2013.

The research was supported by the grant EFOP-3.6.1-16-2016-00001 „Complex improvement of research capacities and services at Eszterhazy Karoly University“

\section{REFERENCES}

Dunkel Z., Kozma F. (1981), A szölö téli kritikus hömérsékleti értékeinek területi eloszlása és gyakorisága Magyarországon. Légkör 26. 2., 13-15.

Ferguson J.C., Julie M., Tarara J.M., Lynn J., Mills, L.J., Grove G.G., Keller M, (2011), Dynamic thermal time model of cold hardiness for dormant grapevine buds, Annals of Botany, 107: 389 - 396.

Ferguson J.C., Moyer M.M., Mills L.J., Hoogenboom G., Keller M. (2014), Modeling Dormant Bud Cold Hardiness and Budbreak in Twenty-ThreeVitis Genotypes Reveals Variation by Region of Origin, American Journal of Enology and Viticulture, 65:1: 59-71.

Lakatos L., Szabó Z., Szalay L., Nyéki J., Racskó J., Soltész M. (2005), A téli és tavaszi fagykárok gyakoriságának valószinüsége magyarországi öszibarack termötájakon. Agro- 21 füzetek. Klímaváltozás - Hatások - Válaszok. 39. 102-114 .

Lakatos L., Szalay L., Szabó Z., Nyéki J. , Racskó J., Soltész M. (2006), A téli és tavaszi fagykárok elöfordulási valószinüsége a föbb magyarországi kajszibarack termötájakon „Agro 21” Füzetek, 45 172-185.

Mills L.J., Ferguson J.C., Keller M. (2006), Cold-Hardiness Evaluation of Grapevine Buds and Cane Tissues,American Journal of Enology and Viticulture. 57: 194-200.

Oláh L.(1979), Szölészek zsebkönyve. Mezőgazdasági Kiadó, pp. 38-42. Budapest.

Szalay L., Papp J., Szabó Z. (2000), Evaluation of frost tolerance of peach varieties in artificial freezing test. Acta Hort. 538:407-410.

Szenteleki K., Gaál M., Ladányi M., Mézes Z., Szabó Z., Zanathy,G., Bisztray Gy. D. (2011), A klímaváltozás hatásai a Közép-magyarországi régió szölö-, meggy- és cseresznyetermesztésére és a termésbiztonságra. Agroinformatikai tanulmányok III (Szerk.: Rózsa T., Szilágyi R.), 113-150.

www.carpatclim-eu.org: A CarpatClim adatbázis és specifikációja. January, 15, 2017. 